\title{
Action Potential Broadening in Capsaicin-Sensitive DRG Neurons from Frequency-Dependent Reduction of Kv3 Current
}

\author{
Pin W. Liu, Nathaniel T. Blair, and Bruce P. Bean \\ Department of Neurobiology, Harvard Medical School, Boston, Massachusetts 02115
}

Action potential (AP) shape is a key determinant of cellular electrophysiological behavior. We found that in small-diameter, capsaicinsensitive dorsal root ganglia neurons corresponding to nociceptors (from rats of either sex), stimulation at frequencies as low as $1 \mathrm{~Hz}$ produced progressive broadening of the APs. Stimulation at $10 \mathrm{~Hz}$ for $3 \mathrm{~s}$ resulted in an increase in AP width by an average of $76 \pm 7 \%$ at $22^{\circ} \mathrm{C}$ and by $38 \pm 3 \%$ at $35^{\circ} \mathrm{C}$. AP clamp experiments showed that spike broadening results from frequency-dependent reduction of potassium current during spike repolarization. The major current responsible for frequency-dependent reduction of overall spikerepolarizing potassium current was identified as $\mathrm{Kv} 3$ current by its sensitivity to low concentrations of 4 -aminopyridine $\left(\mathrm{IC}_{50}<100 \mu \mathrm{M}\right)$ and block by the peptide inhibitor blood depressing substance I (BDS-I). There was a small component of Kv1-mediated current during AP repolarization, but this current did not show frequency-dependent reduction. In a small fraction of cells, there was a component of calcium-dependent potassium current that showed frequency-dependent reduction, but the contribution to overall potassium current reduction was almost always much smaller than that of Kv3-mediated current. These results show that Kv3 channels make a major contribution to spike repolarization in small-diameter DRG neurons and undergo frequency-dependent reduction, leading to spike broadening at moderate firing frequencies. Spike broadening from frequency-dependent reduction in Kv3 current could mitigate the frequency-dependent decreases in conduction velocity typical of C-fiber axons.

Key words: action potential; Kv3 channels; nociceptor; spike broadening

Significance Statement

Small-diameter dorsal root ganglia (DRG) neurons mediating nociception and other sensory modalities express many types of potassium channels, but how they combine to control firing patterns and conduction is not well understood. We found that action potentials of small-diameter rat DRG neurons showed spike broadening at frequencies as low as $1 \mathrm{~Hz}$ and that spike broadening resulted predominantly from frequency-dependent inactivation of Kv3 channels. Spike width helps to control transmitter release, conduction velocity, and firing patterns and understanding the role of particular potassium channels can help to guide new pharmacological strategies for targeting pain-sensing neurons selectively.

\section{Introduction}

The sensation of pain originates in primary afferent sensory neurons and some pathophysiological pain likely involves altered excitability of these neurons (Liu et al., 2000; Chung and Chung, 2002; Katz and Gold, 2006). The excitability of dorsal root ganglia

\footnotetext{
Received June 19, 2017; revised Aug. 29, 2017; accepted Aug. 30, 2017.

Author contributions:P.W.L., N.T.B., and B.P.B. designed research;P.W.L. and N.T.B. performed research;P.W.L.,

N.T.B., and B.P.B. analyzed data; P.W.L., N.T.B., and B.P.B. wrote the paper.

This work was supported by the National Institutes of Health (Grant NS036855).

The authors declare no competing financial interests.

N.T. Blair's present address: Hydra Biosciences, 45 Moulton St., Cambridge, MA 02138.

Correspondence should be addressed to Bruce P. Bean, Department of Neurobiology, Harvard Medical School,

220 Longwood Avenue, Boston, MA 02115. E-mail: bruce_bean@hms.harvard.edu.

DOI:10.1523/JNEUROSCI.1703-17.2017

Copyright $\odot 2017$ the authors $\quad 0270-6474 / 17 / 379705-10 \$ 15.00 / 0$
}

(DRG) neurons corresponding to pain-sensing C-fibers is controlled by the many voltage-dependent ion channels that they express, including multiple types of sodium channels, calcium channels, and potassium channels (Gold et al., 1996; Rasband et al., 2001; Rush et al., 2007; Dib-Hajj et al., 2009; Zamponi et al., 2009). Potassium currents in DRG neurons comprise an especially complex mixture of components, including multiple inactivating and sustained voltage-gated potassium currents (Gold et al., 1996; Safronov et al., 1996; Everill et al., 1998; Rola et al., 2003), calcium-activated potassium currents (Gold et al., 1996; Scholz et al., 1998), and sodium-activated potassium current (Nuwer et al., 2010; Martinez-Espinosa et al., 2015) Reduced potassium currents likely contribute to aberrant nociceptor activity produced by inflammation (Nicol et al., 1997; Vaughn and 
Gold, 2010; Zhang et al., 2012) and nerve injury (Ishikawa et al., 1999; Abdulla and Smith, 2001; Rasband et al., 2001).

Action potential (AP) shape varies considerably among different types of mammalian peripheral and central neurons, reflecting different contributions of various potassium channels. For example, some neocortical GABAergic interneurons have unusually narrow APs that result from large fast-activating currents from Kv3-family channels (Rudy and McBain, 2001; Lien and Jonas, 2003), whereas repolarization of the broader APs of neocortical pyramidal neurons depends on $\mathrm{Kv} 1, \mathrm{Kv} 2$, and $\mathrm{Kv} 4$ channels and BK-calcium-activated potassium channels (Shao et al., 1999; Kim et al., 2005; Liu and Bean, 2014; Pathak et al., 2016). The APs of C-fiber nociceptors are distinctive in being unusually broad, with a pronounced "shoulder" on the falling phase (Ritter and Mendell, 1992; Djouhri et al., 1998). The AP shoulder reflects in part inward voltage-dependent calcium current (McCobb and Beam, 1991; Scroggs and Fox, 1992) and TTX-resistant Nav1.8 channel current (Renganathan et al., 2001; Blair and Bean, 2002) flowing during the falling phase and partially competing with outward potassium currents. The makeup of the potassium currents flowing during AP repolarization in small-diameter nociceptive DRG neurons is not known in detail. Recent experiments suggest that channels formed by Kv3.4 subunits are important because knock-down of Kv3.4 using siRNA results in wider APs (Ritter et al., 2012), a striking result given the previous association of Kv3 channels with cell types with narrow APs. A role of BK-calcium-activated potassium channels in spike repolarization is suggested by the ability of the BK blocker iberiotoxin to broaden APs in some small-diameter DRG neurons (Li et al., 2007; Zhang et al., 2010).

In some neurons, repetitive firing results in broadening of APs, generally appearing to reflect cumulative inactivation of potassium channels. Different potassium channel types are involved in different kinds of neurons. In various molluscan neurons, spike broadening can result from cumulative inactivation of both delayed-rectifier potassium current and A-type potassium current (Aldrich et al., 1979; Ma and Koester, 1996). In hippocampal CA1 pyramidal neurons, inactivation of both BK-calcium-activated potassium channels (Shao et al., 1999) and Kv4-mediated A-type channels (Kim et al., 2005) is involved. Spike broadening in various hypothalamic neurons reflects calcium-dependent progressive inactivation of A-type potassium current (Kirkpatrick and Bourque, 1991, Hlubek and Cobbett, 2000; Sonner et al., 2008). In hippocampal mossy fiber boutons, spike broadening reflects inactivation of a Kv1-mediated component of current, resulting in enhanced calcium entry and enhanced synaptic transmission (Geiger and Jonas, 2000).

Frequency-dependent spike broadening has been described in DRG neurons (Harper and Lawson, 1985; Park and Dunlap, 1998), but the mechanism is unknown. Studying small-diameter, capsaicin-sensitive rat DRG neurons, we found prominent spike broadening at frequencies as low as $1 \mathrm{~Hz}$. Using the AP clamp method and pharmacological dissection of currents, we found that spike broadening in these neurons results primarily from frequency-dependent inactivation of Kv3 channels.

\section{Materials and Methods}

Cell preparation. Dissociated DRG neurons were prepared as described previously (Blair and Bean, 2002). DRGs were removed from LongEvans rats (postnatal day 14-16, either sex), cut in half, and treated for $20 \mathrm{~min}$ at $37^{\circ} \mathrm{C}$ with $20 \mathrm{U} / \mathrm{ml}$ papain (Worthington Biochemical) and $5 \mathrm{~mm}$ DL-cysteine in a $\mathrm{Ca}^{2+}$-free, $\mathrm{Mg}^{2+}$-free (CMF) Hank's solution containing the following (in $\mathrm{mm}$ ): $136.9 \mathrm{NaCl}, 5.4 \mathrm{KCl}, 0.34 \mathrm{Na}_{2} \mathrm{HPO}_{4}$,
A
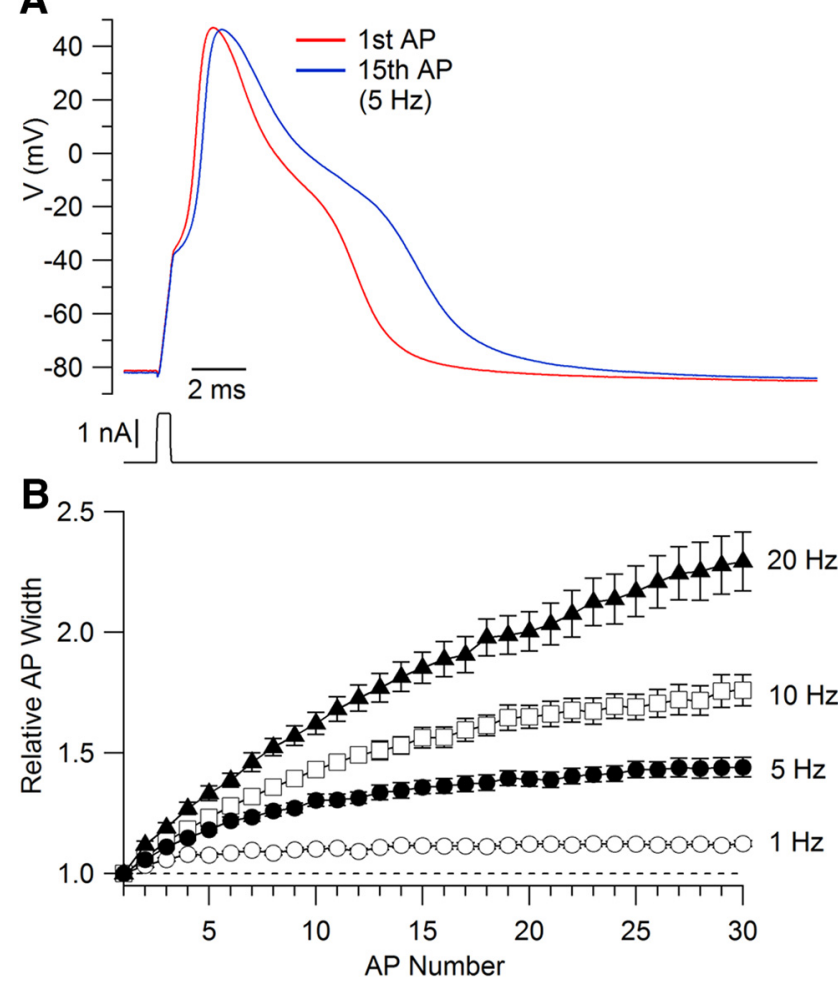

Figure 1. Broadening of APs during repetitive stimulation. A, First and 15th APs evoked by $5 \mathrm{~Hz}$ stimulation in a small-diameter, capsaicin-sensitive DRG neuron. APs were evoked by a $0.5 \mathrm{~ms} 1.7 \mathrm{nA}$ current injection. $\boldsymbol{B}$, Time course of AP broadening with stimulation at frequencies from 1 to $20 \mathrm{~Hz}$. Symbols show mean \pm SEM for determinations at 1, 5, 10, and $20 \mathrm{~Hz}$, each determined in 13 neurons.

$0.44 \mathrm{KH}_{2} \mathrm{PO}_{4}, 5.55$ glucose, and 5 HEPES, $0.005 \%$ phenol red, pH 7.4. Ganglia were then treated for $20 \mathrm{~min}$ at $37^{\circ} \mathrm{C}$ with $3 \mathrm{mg} / \mathrm{ml}$ collagenase (type I; Sigma-Aldrich) and $4 \mathrm{mg} / \mathrm{ml}$ dispase II (Boehringer Mannheim) in CMF Hank's solution. Cells were dispersed by trituration with a firepolished glass Pasteur pipette in a solution of Leibovitz's L-15 medium (Invitrogen) supplemented with 10\% fetal calf serum, 5 mM HEPES, 50 $\mathrm{U} / \mathrm{ml}$ penicillin, $50 \mu \mathrm{g} / \mathrm{ml}$ streptomycin, $2 \mathrm{~mm}$ L-glutamine, and 100 $\mathrm{ng} / \mathrm{ml}$ NGF (Invitrogen) and then plated on glass coverslips treated with $200 \mu \mathrm{g} / \mathrm{ml}$ poly-D-lysine. Cells were incubated in the supplemented L-15 solution at $33^{\circ} \mathrm{C}$ (room air) for $2-4 \mathrm{~h}$, after which they were stored at $4^{\circ} \mathrm{C}$ and used within $48 \mathrm{~h}$. Storing the neurons at $4^{\circ} \mathrm{C}$ inhibited the growth of neurites so that cells could be voltage clamped with fast settling of the capacity transient, enabling accurate recording of currents on the fast time scale of the AP.

Electrophysiology. Whole-cell voltage- and current-clamp recordings were made from small-diameter DRG neurons (21-33 $\mu \mathrm{m})$ using electrodes with resistances of 1.5-6 $\mathrm{M} \Omega$ when filled with a potassiumaspartate internal solution containing the following (in $\mathrm{mM}$ ): 140 K-aspartate, $13.5 \mathrm{NaCl}, 1.6 \mathrm{MgCl}_{2}$, 0.09 EGTA, 9 HEPES, 4 MgATP, 14 Tris-creatine $\mathrm{PO}_{4}$, and 0.3 Tris-GTP, pH 7.4 with KOH. Pipette tips were wrapped with thin strips of Parafilm to reduce capacitance. Seals were formed in Tyrode's solution containing the following (in mM): $150 \mathrm{NaCl}$, $4 \mathrm{KCl}, 2 \mathrm{CaCl}_{2}, 2 \mathrm{MgCl}_{2}, 10$ glucose, and 10 HEPES, pH 7.4 with $\mathrm{NaOH}$. Series resistance was compensated by $80-95 \%$. Solutions were applied after lifting the cell in front of an array of quartz fiber flow pipes. An initial set of experiments was done at room temperature $\left(22 \pm 1^{\circ} \mathrm{C}\right)$ and a subsequent set of experiment was done at $35 \pm 1^{\circ} \mathrm{C}$, with temperature controlled by heating the pipes using a feedback controller system (Warner Instruments TC-344C).

Data acquisition and analysis. Currents and voltages were controlled and sampled using a Digidata $1321 \mathrm{~A}$ or $1322 \mathrm{~A}$ interface and pClamp 8 or pClamp 9 software (Molecular Devices). Current and voltage records were filtered at $5-10 \mathrm{kHz}$ and digitized at $100 \mathrm{kHz}$. Analysis was 
A

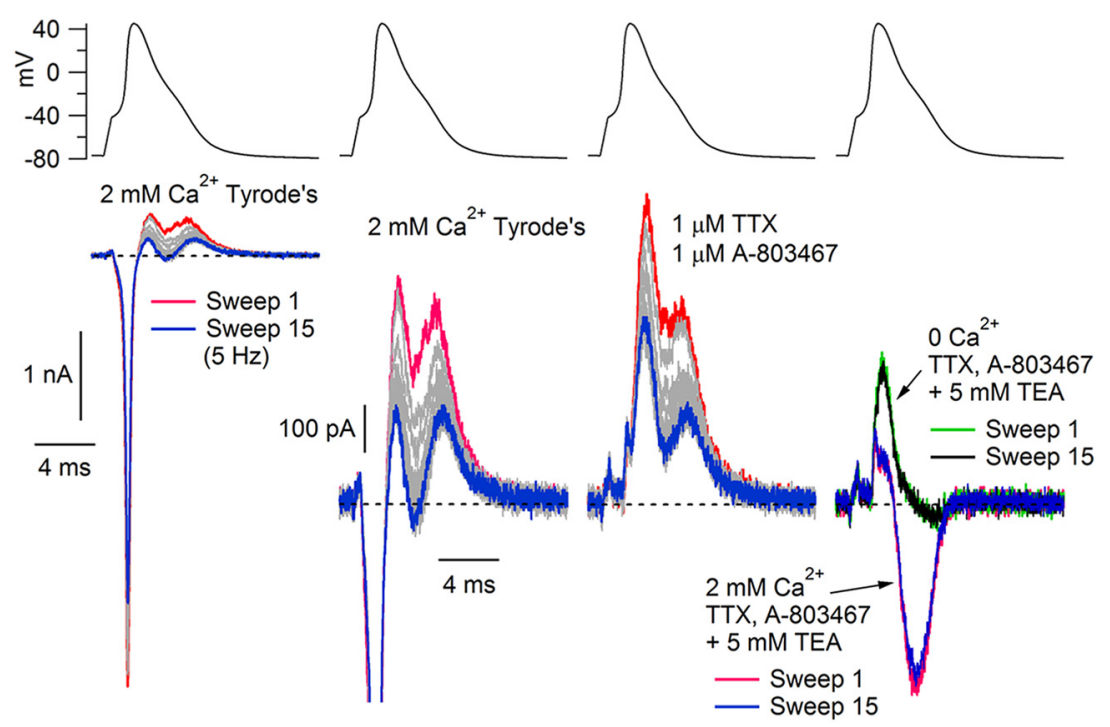

Figure 2. Reduction of outward current evoked by AP waveforms delivered at $5 \mathrm{~Hz}$. The cell's own AP (evoked by a $0.5 \mathrm{~ms}, 1.1 \mathrm{nA}$ current injection) was used as the command waveform in voltage clamp and applied at $5 \mathrm{~Hz}$. A, Successive applications of the AP waveform using control Tyrode's solution containing $2 \mathrm{~mm}$ Ca evoked smaller inward currents during the upstroke and smaller outward currents during repolarization (1st sweep, red; 2nd to 14th sweeps, gray; 15 th sweep, blue). $\boldsymbol{B}$, Outward current shown at higher gain. C, Outward current after inhibiting sodium current with $1 \mu \mathrm{m} \mathrm{TTX}$ and $1 \mu \mathrm{m} A-803467 . D$, Current during first (red) and 15th (blue) sweeps after switching to a solution with $5 \mathrm{~mm}$ TEA added to TTX and A-803467 and then after switching to a solution with TEA, TTX, and A-803467 and with equimolar $\mathrm{Mg}^{2+}$ replacing $\mathrm{Ca}^{2+}$ (first sweep, green; 15 th sweep, black).

performed with Igor Pro (Wavemetrics) using DataAccess (Bruxton Software) to import pClamp data. Reported membrane potentials are corrected for a liquid junction potential of $-10 \mathrm{mV}$ between the internal solution and the Tyrode's solution in which current was zeroed before sealing onto the cell, measured using a flowing $3 \mathrm{~m} \mathrm{KCl}$ reference electrode as described by Neher (1992).

Current-clamp experiments. APs were evoked with $0.5 \mathrm{~ms}$ current injections, leaving most of the AP free of the effect of injected current. For experiments examining frequency-dependent changes in APs during repetitive stimulation, current injections were set to 1.25-1.5 times threshold level to ensure reaching threshold rapidly. When neurons were stimulated repetitively multiple times, neurons were allowed to rest for at least $90 \mathrm{~s}$ between each train. AP widths were measured at half-maximal amplitude.

AP clamp experiments. For most AP clamp experiments (Llinás et al., 1982; de Haas and Vogel, 1989), each cell's own AP was used as the command waveform. Potassium current was quantified by integrating net outward current during the falling phase of AP, starting at the peak of the AP and continuing to the most negative voltage in the afterhyperpolarization (or to 2 times the AP duration in cases in which there was no clear afterhyperpolarization).

Inhibitors. Blood depressing substance I (BDS-I) was from Alomone Laboratories, TTX was from Calbiochem, and $\omega$-conotoxin-GVIA was from Bachem; all other chemicals were from Sigma-Aldrich.

Experimental design and statistical analysis. Summaries of data are given as mean \pm SEM. For assaying frequency-dependent reduction of potassium current during spike repolarization, the experimental measurement was the difference in AP-evoked outward current from the 1st to the 15 th presentation of the AP waveform delivered at $5 \mathrm{~Hz}$. To better allow comparisons among cells, the change in integrated outward current was normalized to each cell's capacitance. The figures show scatter plots of all data for each experimental manipulation (replacement of external calcium by magnesium, addition of tetraethylammonium (TEA), 4 -aminopyridine (4-AP), $\alpha$-dendrotoxin, or BDS-I), with data points from the same cell connected by lines. Statistical significance reported in the text was assessed using the two-tailed Wilcoxon test for nonparametric paired data.

\section{Results}

AP broadening during repetitive stimulation of small DRG neurons

We recorded from small-diameter rat DRG neurons, first testing each cell for capsaicin sensitivity by applying $1 \mu \mathrm{M}$ capsaicin. Only cells in which a current was evoked by capsaicin were studied further. In recording APs from this cell population, we found that with stimulation even at the relatively low frequency of $1 \mathrm{~Hz}$, APs showed progressive spike-to-spike broadening. This effect was quite pronounced at frequencies of $5 \mathrm{~Hz}$ and higher. Figure $1 A$ shows an example with stimulation at $5 \mathrm{~Hz}$ for 3 s. The AP width (measured at halfmaximal amplitude) increased from $4.9 \mathrm{~ms}$ in the first AP to $6.6 \mathrm{~ms}$ in the 15th. Figure $1 B$ shows the frequency dependence of AP broadening in 13 neurons that were each stimulated 30 times at $1,5,10$, and $20 \mathrm{~Hz}$. There was substantial broadening even at $1 \mathrm{~Hz}$ (by $12 \pm 1 \%$ ) and the degree of broadening increased at $5 \mathrm{~Hz}(44 \pm 4 \%)$, $10 \mathrm{~Hz}(76 \pm 7 \%)$, and $20 \mathrm{~Hz}(129 \pm 12 \%)$. Broadening was evident by the second spike in a train and was half-maximal after three to eight spikes, taking longer to reach steady state at higher frequencies. The frequency-dependent spike broadening seen in these cells fits well with AP broadening seen previously during low-frequency stimulation in both rat DRG (Harper and Lawson, 1985) and embryonic chick DRG (Park and Dunlap, 1998) neurons.

To characterize the changes in ionic currents that underlie the AP broadening, we performed AP clamp using each cell's own AP as a command waveform in voltage clamp. We used the first AP recorded during $5 \mathrm{~Hz}$ current-clamp stimulation (i.e., sweep 1 in Fig. 1A) to focus on changes in ionic current resulting from the repetitive application of the same voltage waveform independent of changes resulting from alterations in the shape of the AP. Figure $2 A$ shows an example of the total ionic current recorded in external Tyrode's solution when the AP clamp was applied at $5 \mathrm{~Hz}$. To isolate ionic current, capacitative current was eliminated; most capacitative current was removed electronically using the capacitative nulling circuit in the amplifier and the remaining capacitative current was corrected during analysis by performing a point-by-point subtraction using capacitative currents evoked by a 5 or $10 \mathrm{mV}$ hyperpolarization from $-75 \mathrm{mV}$. As expected, total ionic current was inward during the rising phase of the AP and outward during the falling phase.

With repetitive stimulation by the same AP waveform, there were two changes in the evoked current (Fig. 2A). First, the peak inward current during the AP upstroke decreased. This frequencydependent reduction in inward current during the upstroke results from slow inactivation of TTX-resistant sodium channels (Blair and Bean, 2003). The second change in the current evoked by $5 \mathrm{~Hz}$ stimulation was a decrease in net outward current during the falling phase of the AP. Addition of TTX $(1 \mu \mathrm{M})$ and the Nav1.8 inhibitor A-803467 (1 $\mu \mathrm{M})$ (Jarvis et al., 2007) inhibited the inward sodium current during the rising phase, helping to isolate changes in the outward potassium current. We used TTX 
A
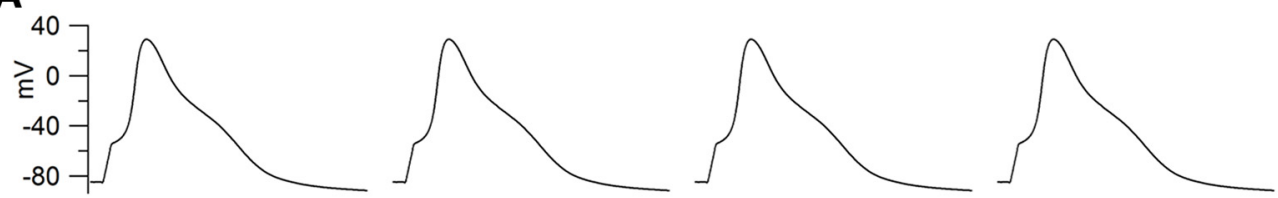

Control $2 \mathrm{mM} \mathrm{Ca}^{2+}$ $2 \mathrm{mM} \mathrm{Ca}^{2+}$
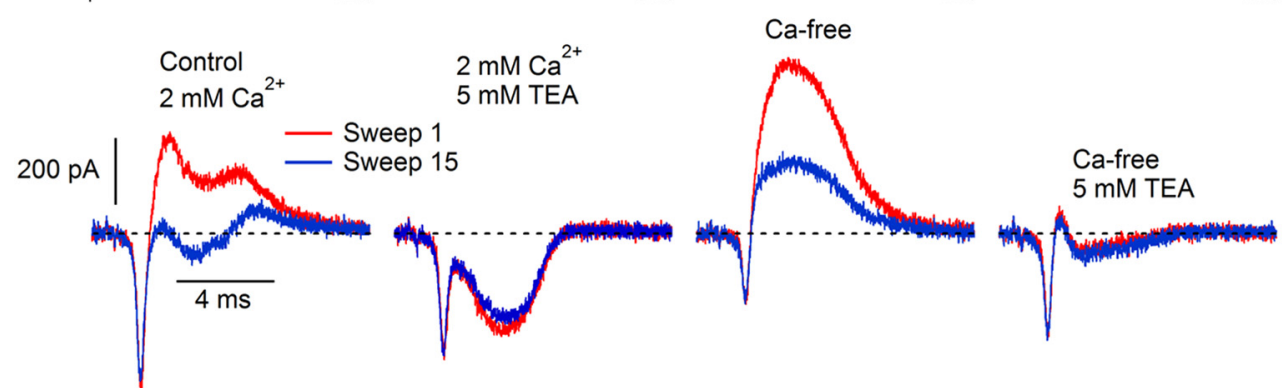

B
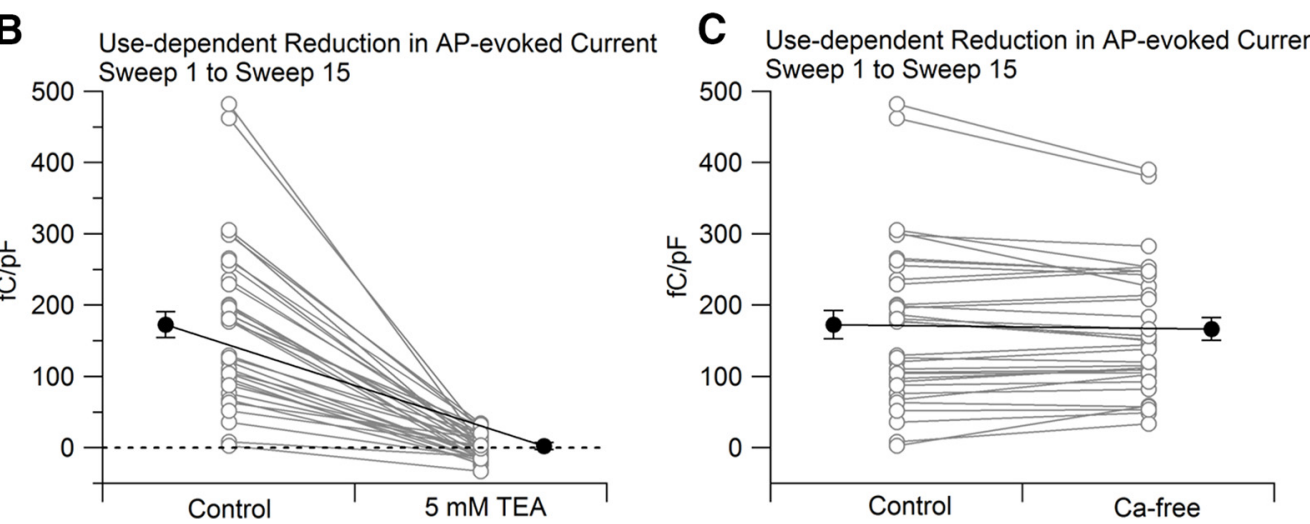

Figure 3. The frequency-dependent component of AP-evoked potassium current is inhibited by $5 \mathrm{~mm}$ TEA and is mostly calcium independent. $A$, Currents evoked by the cell's own AP waveform during the 1st and 15th application of the waveform delivered at $5 \mathrm{~Hz}$, first in Tyrode's solution with $1 \mu \mathrm{M}$ TTX and $1 \mu \mathrm{M} \mathrm{A-803467} \mathrm{(1st,} \mathrm{red;} \mathrm{15th,} \mathrm{blue),} \mathrm{then} \mathrm{in} \mathrm{a} \mathrm{solution} \mathrm{with} \mathrm{added} 5 \mathrm{~mm}$ TEA-Cl, then in a calcium-free solution (with $\mathrm{Mg}^{2+}$ replacing $\mathrm{Ca}^{2+}$ ), and then in the Ca-free solution with added $5 \mathrm{~mm}$ TEA. All solutions contained $1 \mu \mathrm{m}$ TTX and $1 \mu \mathrm{M} \mathrm{A-803467.} \mathrm{B,} \mathrm{Collected} \mathrm{results} \mathrm{from}$ 33 cells showing the change in current evoked by the 1st and the 15th stimuli before and after the addition of $5 \mathrm{~mm}$ TEA. Current was integrated from the peak of the AP to the afterhyperpolarization and normalized to each cells' capacitance. Connected points show data for each cell and solid symbols show mean \pm SEM for each condition. $C$, Same for currents before and after replacing Ca ${ }^{2+}$ by $\mathrm{Mg}^{2+}(n=33)$.

and A-803467 in subsequent experiments to focus on changes in potassium current. In the presence of TTX and A-803467, further addition of $5 \mathrm{~mm}$ TEA inhibited the outward current and resulted in an inward current flowing during the falling phase of the AP, as would be expected if inhibiting potassium current reveals an inward calcium current flowing during the shoulder of the AP. This inward current was eliminated with a solution in which calcium was replaced by magnesium. There was little or no frequencydependent change in the calcium current.

The experiment shown in Figure 2 was typical in that $5 \mathrm{~mm}$ TEA inhibited all or most of the outward potassium current, leaving a net inward calcium current, and there was little or no frequency dependence remaining in the presence of TEA. We quantified the frequency-dependent changes in potassium current by integrating the current during the falling phase of the AP from the time of the peak of the AP to the time of the afterhyperpolarization and calculating the difference in the AP-evoked current in the 1 st and 15 th stimuli delivered at $5 \mathrm{~Hz}$. Figure $3 \mathrm{~A}$ shows records in which we explored the sensitivity of the frequencydependent component of potassium current to external TEA and to removal of calcium. TEA completely inhibited the frequencydependent component of outward current. In collected results from 33 cells, there was a use-dependent reduction in outward current during the falling phase of the AP of $172 \pm 20 \mathrm{fC} / \mathrm{pF}$ (outward current integrated during the falling phase of the AP and normalized to each cell's capacitance) and this was reduced to $2 \pm 3 \mathrm{fC} / \mathrm{pF}$ in the presence of $5 \mathrm{~mm} \mathrm{TEA}(n=33 ; p<0.0001$, two-tailed Wilcoxon test).

Previous work has shown that BK-calcium-activated potassium channels contribute to the repolarization of APs in smalldiameter DRG neurons (Gold et al., 1996; Scholz et al., 1998; Li et al., 2007; Zhang et al., 2010, 2012; Cao et al., 2012). BK channels are sensitive to external TEA and, with some combinations of accessory subunits, can undergo inactivation (Wallner et al., 1999; Xia et al., 1999, 2000). We therefore tested whether the frequency-dependent component of potassium current was from calcium-activated potassium channels by using solutions in which calcium was replaced by magnesium. In most cells, replacing calcium with magnesium had little effect on the frequency-dependent component of potassium current (Fig. 3C). On average, the frequency-dependent component of potassium current decreased from $170 \pm 20 \mathrm{fC} / \mathrm{pF}$ in calcium-containing solution to $166 \pm 16 \mathrm{fC} / \mathrm{pF}$ in calcium-free solution $(n=33 ; p=$ 0.64 , two-tailed Wilcoxon test). In a small fraction of cells (seven of 33), eliminating calcium resulted in a clear reduction of frequencydependent current by $>10 \%$, suggestive of a component of frequency-dependent BK current. However, this component was always much smaller than the component of frequency-dependent current remaining in calcium-free solution. We therefore focused on this calcium-independent component in further experiments. 

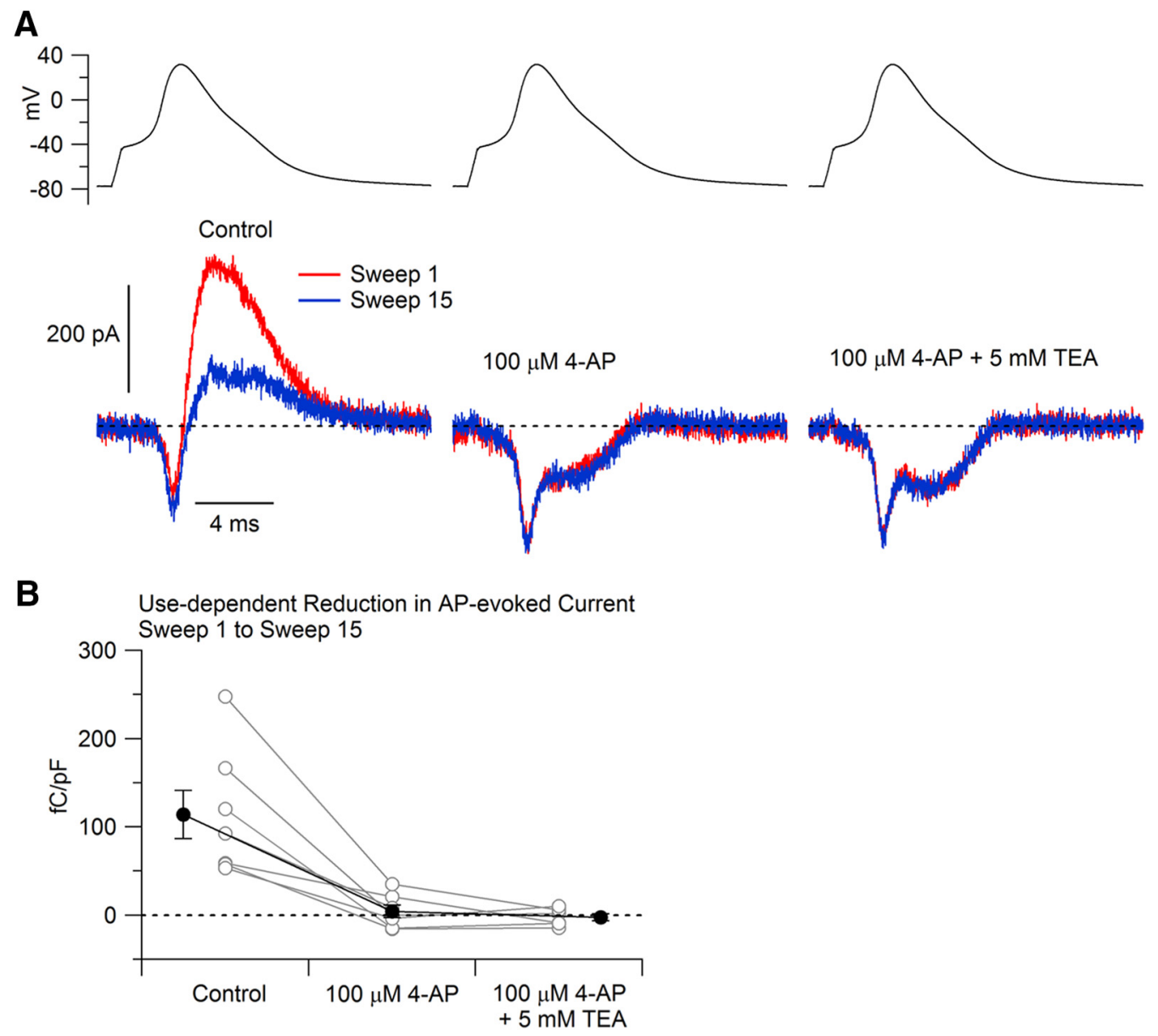

Figure 4. Effect of $100 \mu \mathrm{m} 4-\mathrm{AP}$ on frequency-dependent reduction in potassium current. $A$, Currents evoked by the cell's AP waveform during the 1st and 15th application of the waveform delivered at $5 \mathrm{~Hz}$ before (left), after (middle) applying $100 \mu \mathrm{m}$ 4-AP, and after applying $100 \mu \mathrm{m}$ 4-AP together with $5 \mathrm{~mm} \mathrm{TEA} \mathrm{(right).} \mathrm{Currents} \mathrm{were} \mathrm{recorded} \mathrm{in} \mathrm{a} \mathrm{solution} \mathrm{containing} 1 \mu \mathrm{m} \mathrm{TTX} \mathrm{and}$ $1 \mu \mathrm{m}$ A-803467 to inhibit sodium current and with $\mathrm{Mg}^{2+}$ replacing $\mathrm{Ca}^{2+}$ to eliminate calcium current. $\boldsymbol{B}$, Collected results showing the change in current evoked by the 1st and the 15 th stimuli before and after $100 \mu \mathrm{m}$ 4-AP and then $100 \mu \mathrm{m}$ 4-AP plus $5 \mathrm{~mm}$ TEA. Connected points show data for each cell ( $n=7$ for control/4-AP, $n=6$ for control/4-AP/4-AP + TEA) and solid symbols show mean \pm SEM for each condition.

To explore what channel types underlie the calcium-independent potassium current, we next tested the effect of various inhibitors on the frequency-sensitive potassium current. We first tested its sensitivity to 4 -AP. We found that 4 -AP applied at $100 \mu \mathrm{M}$ was very effective at inhibiting the frequency-dependent component of the potassium current. An example is shown in Figure $4 A$, in which $100 \mu \mathrm{M} 4$-AP completely inhibited the frequency-dependent component of potassium current and there was little effect of further addition of 5 mM TEA. In collected results, $100 \mu \mathrm{M} 4$-AP reduced the frequency-dependent potassium current from $114 \pm 27 \mathrm{fC} / \mathrm{pF}$ to $4 \pm 7 \mathrm{fC} / \mathrm{pF}(n=7 ; p<$ 0.01, Wilcoxon two-tailed test).

Although many types of potassium channels are inhibited by millimolar concentrations of 4-AP, only a few are effectively inhibited by submillmolar concentrations. Among the currents with high sensitivity to 4-AP are two kinds of potassium currents that can undergo inactivation, a Kv1-mediated current known as $I_{\mathrm{D}}$ (Storm, 1988; Wu and Barish, 1992; Shu et al., 2007) and Kv3 channels that include the Kv3.4 subunit (Rettig et al., 1992; Diochot et al., 1998; Baranauskas et al., 2003). We therefore tested more selective inhibitors of each of these currents. $I_{\mathrm{D}}$ is sensitive to the peptide inhibitor $\alpha$-dendrotoxin, which inhibits the Kv1mediated component of inactivating potassium current that underlies spike broadening in mossy fiber terminals in the hip- pocampus (Geiger and Jonas, 2000). However, we found that there was very little effect of $\alpha$-dendrotoxin on the frequencydependent component of current in small-diameter, capsaicinsensitive DRG neurons (Fig. 5). On average, frequency-dependent potassium current changed from $160 \pm 34 \mathrm{fC} / \mathrm{pF}$ to $158 \pm 29 \mathrm{fC} / \mathrm{pF}$ with application of $200 \mathrm{nM} \alpha$-dendrotoxin $(n=10 ; p=0.67$, Wilcoxon two-tailed test).

We next tested the Kv3 inhibitor BDS-I (Diochot et al., 1998; Shevchenko et al., 2004; Yeung et al., 2005; Martina et al., 2007). BDS-I almost completely inhibited the frequency-dependent potassium current, reducing it from $174 \pm 37 \mathrm{fC} / \mathrm{pF}$ to $1 \pm 3 \mathrm{fC} / \mathrm{pF}$ (Fig. $5 ; n=9, p<0.05$, Wilcoxon two-tailed test). The combination of sensitivity to low concentrations of 4-AP and BDS-I suggests that the frequency-dependent component of potassium current is carried by Kv3 channels.

\section{AP broadening at $35^{\circ} \mathrm{C}$}

The kinetics of channel gating are strongly temperature dependent (Hille, 2001). The kinetics of potassium channels during the AP are expected to change with changes in temperature. We therefore did a series of experiments examining spike broadening at near-physiological temperature $\left(35^{\circ} \mathrm{C}\right)$. We found that APs at $35^{\circ} \mathrm{C}$ showed frequency-dependent broadening (Fig. 6). As at room temperature, broadening was evident at frequencies as 

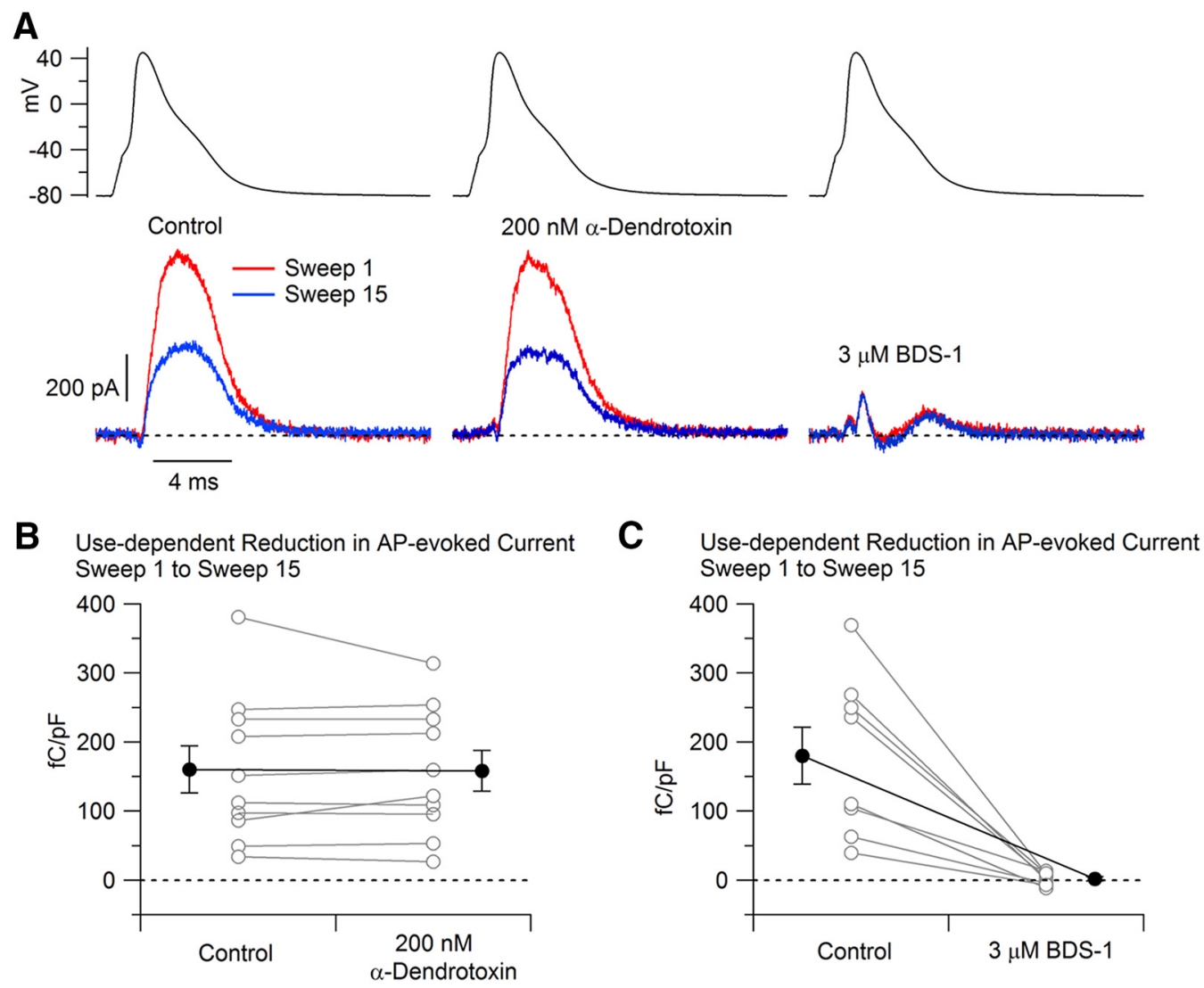

Figure 5. Effect of $\alpha$-dendrotoxin and BDS-I on frequency-dependent reduction in potassium current. $A$, Currents evoked by the 1st and 15th AP waveforms are shown in control (left), after the application of $200 \mathrm{~nm} \alpha$-dendrotoxin (middle), and after the application of $3 \mu \mathrm{m} \mathrm{BDS-I} \mathrm{(right).} \mathrm{Currents} \mathrm{were} \mathrm{recorded} \mathrm{in} \mathrm{a} \mathrm{solution} \mathrm{containing} 1 \mu \mathrm{m} \mathrm{TTX} \mathrm{and} 1 \mu \mathrm{m} \mathrm{A-803467} \mathrm{to} \mathrm{inhibit} \mathrm{sodium} \mathrm{current}$ and with $\mathrm{Mg}^{2+}$ replacing $\mathrm{Ca}^{2+}$ to eliminate calcium current. $B$, Collected results showing the change in current evoked by the 1st and 15th stimuli before and after $200 \mathrm{~nm}$ dendrotoxin. Connected points show data for each cell $(n=10)$ and solid symbols show mean \pm SEM for each condition. C, Same for currents before and after application of $3 \mu \mathrm{m}$ BDS-I to the external solution $(n=9)$.

low as $1 \mathrm{~Hz}$, but it took higher frequencies for a given degree of broadening at $35^{\circ} \mathrm{C}$ compared with room temperature. In collected results, the amount of broadening during $30 \mathrm{APs}$ at $35^{\circ} \mathrm{C}$ was $12 \pm 2 \%$ at $1 \mathrm{~Hz}(n=16), 25 \pm 3 \%$ at $5 \mathrm{~Hz}(n=16), 38 \pm 3 \%$ at $10 \mathrm{~Hz}(n=13)$, and $67 \pm 10 \%$ at $20 \mathrm{~Hz}(n=11)$.

As at $22^{\circ} \mathrm{C}$, the outward current evoked by APs at $35^{\circ} \mathrm{C}$ showed a frequency-dependent reduction. Furthermore, as at $22^{\circ} \mathrm{C}$, BDS-I very effectively inhibited the frequency-dependent component of potassium current for APs at $35^{\circ} \mathrm{C}$ (Fig. 7), reducing it from $83 \pm$ $18 \mathrm{fC} / \mathrm{pF}$ to $1 \pm 5 \mathrm{fC} / \mathrm{pF}(n=10 ; p=0.0054$, two-tailed Wilcoxon test). Therefore, it appears that Kv3 channels account for the inactivation of potassium channels producing frequency-dependent APs at $35^{\circ} \mathrm{C}$ as well as at $22^{\circ} \mathrm{C}$.

\section{Discussion}

These results show that, as in a number of other neuronal types, APs in small-diameter, capsaicin-sensitive DRG neurons show frequency-dependent broadening. AP clamp experiments show that the broadening results from frequency-dependent reduction of potassium current during the falling phase of the AP and that Kv3 channels account for most of the potassium current undergoing frequency-dependent reduction.

We examined AP broadening at frequencies between 1 and $20 \mathrm{~Hz}$, which is within the range of firing frequencies seen in C-fiber nociceptors in response to noxious stimuli such as pinch (Chen and Levine, 2003; Djouhri et al., 2006). In fact, at the onset of mechanical stimulation, C-fiber nociceptors can fire up to $60 \mathrm{~Hz}$, with firing as fast as $20 \mathrm{~Hz}$ sustained for several hundred milliseconds (Chen and Levine, 2003). We saw substantial broadening at $20 \mathrm{~Hz}$ (increase in spike width by $\sim 60 \%$ in the first half-second) suggesting that significant broadening likely occurs at physiological rates of firing.

\section{Kv3 channels}

The identification of $\mathrm{Kv} 3$ channels as the key channels underlying spike broadening fits well with recent work showing expression of both Kv3.1 subunits (Bocksteins et al., 2012) and Kv3.4 subunits Chien et al., 2007; Ritter et al., 2012; Ritter et al., 2015a) in small DRG neurons. Kv3.4 subunits confer rapid inactivation on both homomeric and heteromeric channels (Rettig et al., 1992; Diochot et al., 1998; Baranauskas et al., 2003). An inactivating component of current in small DRG neurons can be reduced using siRNA for Kv3.4 (Ritter at al., 2012) and was found to be activated early in spike repolarization (Ritter et al., 2015b), which is consistent with our results. The inactivating component of current matches the properties of a component of overall potassium current in small DRG neurons originally called $I_{\text {Aht }}$ (Gold et al., 1996).

The key involvement of Kv3 channels in spike broadening is at first surprising. Kv3 family channels were initially associated with fast-spiking neocortical interneurons and cerebellar Purkinje neurons, both of which have narrow APs (half-amplitude width $100-500 \mu \mathrm{s})$ and can fire at high frequencies without reported spike broadening (Rudy et al., 1999; Rudy and McBain, 2001; Lien and Jonas, 2003; Martina et al., 2007). The reasons that inactivation of $\mathrm{Kv} 3$ channels produces spike broadening in DRG 
A $35{ }^{\circ} \mathrm{C}$
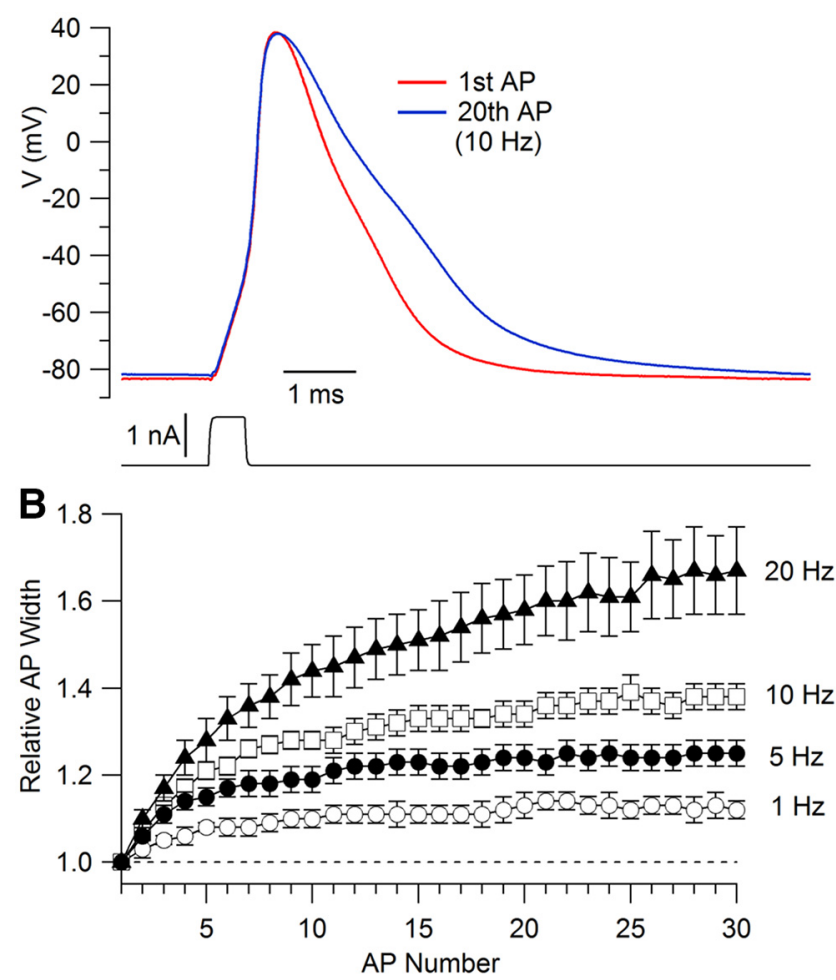

Figure 6. Broadening of APs during repetitive stimulation at $35^{\circ} \mathrm{C}$. $A$, First and 15 th APs evoked by $5 \mathrm{~Hz}$ stimulation. $\boldsymbol{B}$, Time course of AP broadening with stimulation at different frequencies. Symbols show mean \pm SEM for determinations at $1 \mathrm{~Hz}(n=16), 5 \mathrm{~Hz}(n=16)$, $10 \mathrm{~Hz}(n=13)$, and $20 \mathrm{~Hz}(n=11)$.

neurons, but apparently not in interneurons or Purkinje neurons, remain to be determined. In Purkinje neurons, with narrow APs, only a small fraction (20\%) of available channels is actually activated during spike repolarization (Martina et al., 2007). With a large "buffer" of potassium current not normally activated, perhaps a small increase in AP duration can recruit a larger fraction of channels and thus limit spike broadening even if a fraction of the channels inactivate. When APs are already broad, as in small DRG neurons, available channels may be activated with a higher probability to start with (Ritter et al., 2015a) so that there is little or no buffer to compensate for reduction of available channels by inactivation. It is also possible that the kinetics of activation or inactivation of Kv3 channels are different in DRG neurons and fast-spiking neurons. Further voltage-clamp experiments will be needed to explore these possibilities.

\section{BK channels}

In most cells, the component of potassium current undergoing frequency-dependent reduction was little affected by removal of calcium. However, there was significant reduction by $>10 \%$ in a minority of neurons (seven of 33). It is plausible that this represents a component of inactivating BK current. There is expression of BK current in small DRG neurons (Zhang et al., 2003; Zhang et al., 2010; Hendrich et al., 2012; cf. Cao et al., 2012) and, in some small DRG neurons, blocking BK current produces broadening of APs (Scholz et al., 1998; Zhang et al., 2003; Li et al., 2007; Zhang et al., 2010; Cao et al., 2012). BK channels can undergo inactivation when $\beta 2$ and $\beta 3$ subunits are expressed (Wallner et al., 1999; Xia et al., 1999, 2000) and both are found to be present in DRG neurons by single-cell PCR (Zhang et al., 2012).
A $35^{\circ} \mathrm{C}$
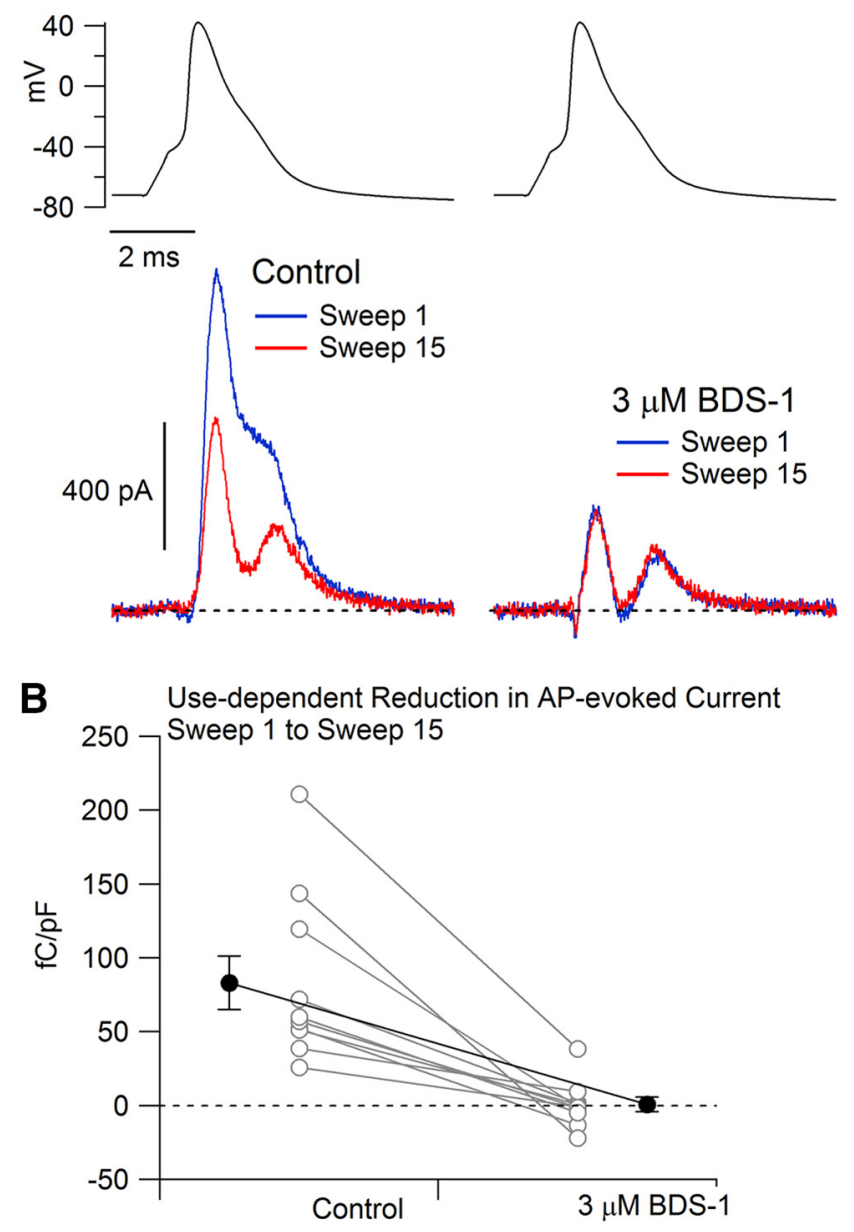

Figure 7. Frequency-dependent reduction in AP-evoked potassium current at $35^{\circ} \mathrm{C}$ is mainly from Kv3 channels. $A$, Current evoked by the cell's AP waveform was recorded with the waveform delivered at $5 \mathrm{~Hz}$. Currents evoked by the 1st and 15th AP waveforms are shown in control (left) and after the application of $3 \mu \mathrm{m}$ BDS-I (right) to inhibit Kv3 channels. Currents were recorded in a solution containing $1 \mu \mathrm{M}$ TTX and $1 \mu \mathrm{M}$ A-803467 to inhibit sodium current. $B$, Collected results showing the change in current evoked by the 1 st and 15 th stimuli before and after the addition of $3 \mu \mathrm{m}$ BDS-I to the external solution. Connected points show data for each cell $(n=10)$ and solid symbols show mean \pm SEM for each condition.

However, the contribution of BK channel inactivation to overall frequency-dependent reduction of potassium current is clearly small relative to that of $\mathrm{Kv} 3$ current and is unlikely to contribute significantly to spike broadening in most neurons.

\section{Kv1 channels}

In voltage-clamp experiments using voltage steps, the overall potassium current in small DRG neurons includes a component of $\alpha$-dendrotoxin-sensitive Kv1 current in both mice (Beekwilder et al., 2003; Bocksteins et al., 2012) and rats (Yang et al., 2004; Gruss et al., 2006; Chi and Nicol, 2007; Sculptoreanu et al., 2009), However, dendrotoxin has little effect on AP duration (Chi and Nicol, 2007). Consistent with this, in our experiments, $\alpha$-dendrotoxin inhibited only a very small component of overall potassium current evoked by AP waveforms and had very little effect on the potassium current undergoing frequency-dependent reduction during repetitive firing. The simplest interpretation is that, although small DRG neurons express Kv1 channels, they likely activate too slowly to be activated much during APs compared with fast-activating Kv3 channels. 


\section{Comparison with other neurons}

Spike broadening from Kv3 channel inactivation has not been described before and may be unusual. In hippocampal mossy fiber boutons, Kv3 channels contribute $\sim 60 \%$ of the AP-evoked potassium current (Alle et al., 2011), but spike broadening is ascribed to inactivation of Kv1-mediated current (Geiger and Jonas, 2000). In hypothalamic supraoptic neurons, Kv3 channels help to mediate spike repolarization (Shevchenko et al., 2004), but spike broadening is attributed to inactivation of other potassium channels (Hlubek and Cobbett, 2000) and facilitation of calcium currents (O'Regan and Cobbett, 1993).

Spike broadening in DRG neurons was substantial at much lower frequencies than required in most other neuronal types. For example, in CA1 pyramidal neurons, frequencies $>20 \mathrm{~Hz}$ are needed to produce spike broadening (Shao et al., 1999), similar to amygdala neurons, in which BK channels also mediate broadening (Faber and Sah, 2003). In contrast, in capsaicin-sensitive DRG neurons, spike broadening was evident at $1 \mathrm{~Hz}$ and very dramatic at $20 \mathrm{~Hz}\left(67 \pm 10 \%\right.$ at $\left.35^{\circ} \mathrm{C}\right)$. The rapid onset of spike broadening (by the second spike) fits with the fast onset of inactivation of Kv3.4-containing channels and its occurrence at frequencies as low as $1 \mathrm{~Hz}$ fits with the slow recovery of inactivation, which takes several seconds at room temperature (Rettig et al., 1992; Baranauskas et al., 2003).

\section{Functional significance of spike broadening in small DRG neurons}

Immunocytochemistry shows the expression of Kv3.4 channels in axons and synaptic boutons of C-fibers and in cell bodies (Chien et al., 2007), making it plausible that AP broadening could occur in axons and boutons as well. At boutons, spike broadening would result in increased calcium entry (Jackson et al., 1991) and transmitter release (Geiger and Jonas, 2000). In axons, other things being equal, a broader AP should promote faster conduction with a larger safety factor because the longer depolarization prolongs the passive electrotonic depolarization of the downstream axon that initiates active recruitment of sodium channels. This might explain why APs of small DRG neurons associated with small-diameter, slowly conducting $\mathrm{C}$-fiber axons are notable for being unusually broad to begin with (Harper and Lawson, 1985; Koerber et al., 1988; Djouhri et al., 1998). Frequencydependent spike broadening could then help to mitigate activitydependent slowing of conduction velocity and spike failure resulting from slow inactivation of sodium channels (De Col et al., 2008, 2012) and accumulation of intraaxonal sodium (Tigerholm et al., 2014). Currently, however, our mechanistic understanding of AP propagation in C-fiber axons is necessarily based mainly on computer modeling (Gemes et al., 2013; Petersson et al., 2014; Tigerholm et al., 2014; Sundt et al., 2015). Further data on the nature and kinetics of the potassium currents flowing during the AP should allow such modeling to be increasingly realistic and lead to new insights about how the many types of ion channels in C-fiber neurons combine to regulate excitability during natural firing patterns.

\section{References}

Abdulla FA, Smith PA (2001) Axotomy- and autotomy-induced changes in $\mathrm{Ca} 2+$ and $\mathrm{K}+$ channel currents of rat dorsal root ganglion neurons. J Neurophysiol 85:644-658. Medline

Aldrich RW Jr, Getting PA, Thompson SH (1979) Mechanism of frequencydependent broadening of molluscan neurone soma spikes. J Physiol 291: 531-544. CrossRef Medline

Alle H, Kubota H, Geiger JR (2011) Sparse but highly efficient Kv3 outpace
BKCa channels in action potential repolarization at hippocampal mossy fiber boutons. J Neurosci 31:8001-8012. CrossRef Medline

Baranauskas G, Tkatch T, Nagata K, Yeh JZ, Surmeier DJ (2003) Kv3.4 subunits enhance the repolarizing efficiency of Kv3.1 channels in fast-spiking neurons. Nat Neurosci 6:258-266. CrossRef Medline

Beekwilder JP, O'Leary ME, van den Broek LP, van Kempen GT, Ypey DL, van den Berg RJ (2003) Kv1.1 channels of dorsal root ganglion neurons are inhibited by n-butyl-p-aminobenzoate, a promising anesthetic for the treatment of chronic pain. J Pharmacol Exp Ther 304:531-538. CrossRef Medline

Blair NT, Bean BP (2002) Roles of tetrodotoxin (TTX)-sensitive na + current, TTX-resistant na + current, and Ca2 + current in the action potentials of nociceptive sensory neurons. J Neurosci 22:10277-10290. Medline

Blair NT, Bean BP (2003) Role of tetrodotoxin-resistant na + current slow inactivation in adaptation of action potential firing in small-diameter dorsal root ganglion neurons. J Neurosci 23:10338-10350. Medline

Bocksteins E, Van de Vijver G, Van Bogaert PP, Snyders DJ (2012) Kv3 channels contribute to the delayed rectifier current in small cultured mouse dorsal root ganglion neurons. Am J Physiol Cell Physiol 303: C406-C415. CrossRef Medline

Cao XH, Chen SR, Li L, Pan HL (2012) Nerve injury increases brain-derived neurotrophic factor levels to suppress BK channel activity in primary sensory neurons. J Neurochem 121:944-953. CrossRef Medline

Chen X, Levine JD (2003) Altered temporal pattern of mechanically evoked C-fiber activity in a model of diabetic neuropathy in the rat. Neuroscience 121:1007-1015. CrossRef Medline

Chi XX, Nicol GD (2007) Manipulation of the potassium channel Kv1.1 and its effect on neuronal excitability in rat sensory neurons. J Neurophysiol 98:2683-2692. CrossRef Medline

Chien LY, Cheng JK, Chu D, Cheng CF, Tsaur ML (2007) Reduced expression of A-type potassium channels in primary sensory neurons induces mechanical hypersensitivity. J Neurosci 27:9855-9865. CrossRef Medline

Chung JM, Chung K (2002) Importance of hyperexcitability of DRG neurons in neuropathic pain. Pain Pract 2:87-97. CrossRef Medline

De Col R, Messlinger K, Carr RW (2008) Conduction velocity is regulated by sodium channel inactivation in unmyelinated axons innervating the rat cranial meninges. J Physiol 586:1089-1103. CrossRef Medline

De Col R, Messlinger K, Carr RW (2012) Repetitive activity slows axonal conduction velocity and concomitantly increases mechanical activation threshold in single axons of the rat cranial dura. J Physiol 590:725-736. CrossRef Medline

de Haas V, Vogel W (1989) Sodium and potassium currents recorded during an action potential. Eur Biophys J 17:49-51. CrossRef Medline

Dib-Hajj SD, Black JA, Waxman SG (2009) Voltage-gated sodium channels: therapeutic targets for pain. Pain Med 10:1260-1269. CrossRef Medline

Diochot S, Schweitz H, Béress L, Lazdunski M (1998) Sea anemone peptides with a specific blocking activity against the fast inactivating potassium channel Kv3.4. J Biol Chem 273:6744-6749. CrossRef Medline

Djouhri L, Bleazard L, Lawson SN (1998) Association of somatic action potential shape with sensory receptive properties in guinea-pig dorsal root ganglion neurones. J Physiol 513:857-872. CrossRef Medline

Djouhri L, Koutsikou S, Fang X, McMullan S, Lawson SN (2006) Spontaneous pain, both neuropathic and inflammatory, is related to frequency of spontaneous firing in intact C-fiber nociceptors. J Neurosci 26:12811292. CrossRef Medline

Everill B, Rizzo MA, Kocsis JD (1998) Morphologically identified cutaneous afferent DRG neurons express three different potassium currents in varying proportions. J Neurophysiol 79:1814-1824. Medline

Faber ES, Sah P (2003) Ca2 +-activated K+ (BK) channel inactivation contributes to spike broadening during repetitive firing in the rat lateral amygdala. J Physiol 552:483-497. CrossRef Medline

Geiger JR, Jonas P (2000) Dynamic control of presynaptic ca(2+) inflow by fast-inactivating $\mathrm{K}(+)$ channels in hippocampal mossy fiber boutons. Neuron 28:927-939. CrossRef Medline

Gemes G, Koopmeiners A, Rigaud M, Lirk P, Sapunar D, Bangaru ML, Vilceanu D, Garrison SR, Ljubkovic M, Mueller SJ, Stucky CL, Hogan QH (2013) Failure of action potential propagation in sensory neurons: Mechanisms and loss of afferent filtering in C-type units after painful nerve injury. J Physiol 591:1111-1131. CrossRef Medline

Gold MS, Shuster MJ, Levine JD (1996) Characterization of six voltagegated K+ currents in adult rat sensory neurons. J Neurophysiol 75:26292646. Medline 
Gruss M, Ettorre G, Stehr AJ, Henrich M, Hempelmann G, Scholz A (2006) Moderate hypoxia influences excitability and blocks dendrotoxin sensitive $\mathrm{K}+$ currents in rat primary sensory neurones. Mol Pain 2:12. Medline

Harper AA, Lawson SN (1985) Electrical properties of rat dorsal root ganglion neurones with different peripheral nerve conduction velocities. J Physiol 359:47-63. CrossRef Medline

Hendrich J, Alvarez P, Chen X, Levine JD (2012) GDNF induces mechanical hyperalgesia in muscle by reducing $\mathrm{I}(\mathrm{BK})$ in isolectin B4-positive nociceptors. Neuroscience 219:204-213. CrossRef Medline

Hille B (2001) Ion channels of excitable membranes, Ed 3. Sunderland, MA: Sinauer.

Hlubek MD, Cobbett P (2000) Differential effects of K(+) channel blockers on frequency-dependent action potential broadening in supraoptic neurons. Brain Res Bull 53:203-209. CrossRef Medline

Ishikawa K, Tanaka M, Black JA, Waxman SG (1999) Changes in expression of voltage-gated potassium channels in dorsal root ganglion neurons following axotomy. Muscle Nerve 22:502-507. CrossRef Medline

Jackson MB, Konnerth A, Augustine GJ (1991) Action potential broadening and frequency-dependent facilitation of calcium signals in pituitary nerve terminals. Proc Natl Acad Sci U S A 88:380-384. CrossRef Medline

Jarvis MF, et al. (2007) A-803467, a potent and selective Nav1.8 sodium channel blocker, attenuates neuropathic and inflammatory pain in the rat. Proc Natl Acad Sci U S A 104:8520-8855. CrossRef Medline

Katz EJ, Gold MS (2006) Inflammatory hyperalgesia: A role for the C-fiber sensory neuron cell body? J Pain 7:170-178. Medline

Kim J, Wei DS, Hoffman DA (2005) Kv4 potassium channel subunits control action potential repolarization and frequency-dependent broadening in rat hippocampal CA1 pyramidal neurones. J Physiol 569:41-57. CrossRef Medline

Kirkpatrick K, Bourque CW (1991) Dual role for calcium in the control of spike duration in rat supraoptic neuroendocrine cells. Neurosci Lett 133: 271-274. CrossRef Medline

Koerber HR, Druzinsky RE, Mendell LM (1988) Properties of somata of spinal dorsal root ganglion cells differ according to peripheral receptor innervated. J Neurophysiol 60:1584-1596. Medline

Li W, Gao SB, Lv CX, Wu Y, Guo ZH, Ding JP, Xu T (2007) Characterization of voltage-and $\mathrm{Ca} 2+$-activated $\mathrm{K}+$ channels in rat dorsal root ganglion neurons. J Cell Physiol 212:348-357. CrossRef Medline

Lien CC, Jonas P (2003) Kv3 potassium conductance is necessary and kinetically optimized for high-frequency action potential generation in hippocampal interneurons. J Neurosci 23:2058-2068. Medline

Liu CN, Michaelis M, Amir R, Devor M (2000) Spinal nerve injury enhances subthreshold membrane potential oscillations in DRG neurons: Relation to neuropathic pain. J Neurophysiol 84:205-215. Medline

Liu PW, Bean BP (2014) Kv2 channel regulation of action potential repolarization and firing patterns in superior cervical ganglion neurons and hippocampal CA1 pyramidal neurons. J Neurosci 34:4991-5002. CrossRef Medline

Llinás R, Sugimori M, Simon SM (1982) Transmission by presynaptic spike-like depolarization in the squid giant synapse. Proc Natl Acad Sci U S A 79:2415-2419. CrossRef Medline

Ma M, Koester J (1996) The role of K+ currents in frequency-dependent spike broadening in aplysia R20 neurons: a dynamic-clamp analysis. J Neurosci 16:4089-4101. Medline

Martina M, Metz AE, Bean BP (2007) Voltage-dependent potassium currents during fast spikes of rat cerebellar purkinje neurons: Inhibition by BDS-I toxin. J Neurophysiol 97:563-571. CrossRef Medline

Martinez-Espinosa PL, Wu J, Yang C, Gonzalez-Perez V, Zhou H, Liang H, Xia XM, Lingle CJ (2015) Knockout of Slo2.2 enhances itch, abolishes $\mathrm{KNa}$ current, and increases action potential firing frequency in DRG neurons. Elife 4: pii: e10013. CrossRef Medline

McCobb DP, Beam KG (1991) Action potential waveform voltage-clamp commands reveal striking differences in calcium entry via low and high voltage-activated calcium channels. Neuron 7:119-127. CrossRef Medline

Neher E (1992) Correction for liquid junction potentials in patch clamp experiments. Methods Enzymol 207:123-131. CrossRef Medline

Nicol GD, Vasko MR, Evans AR (1997) Prostaglandins suppress an outward potassium current in embryonic rat sensory neurons. J Neurophysiol 77:167-176. Medline

Nuwer MO, Picchione KE, Bhattacharjee A (2010) PKA-induced internalization of slack $\mathrm{KNa}$ channels produces dorsal root ganglion neuron hyperexcitability. J Neurosci 30:14165-14172. CrossRef Medline
O’Regan MH, Cobbett P (1993) Somatic currents contribute to frequencydependent spike-broadening in supraoptic neuroendocrine cells. Neurosci Lett 161:169-173. CrossRef Medline

Park D, Dunlap K (1998) Dynamic regulation of calcium influx by G-proteins, action potential waveform, and neuronal firing frequency. J Neurosci 18: 6757-6766. Medline

Pathak D, Guan D, Foehring RC (2016) Roles of specific Kv channel types in repolarization of the action potential in genetically identified subclasses of pyramidal neurons in mouse neocortex. J Neurophysiol 115:2317-2329. CrossRef Medline

Petersson ME, Obreja O, Lampert A, Carr RW, Schmelz M, Fransén E (2014) Differential axonal conduction patterns of mechano-sensitive and mechanoinsensitive nociceptors-a combined experimental and modelling study. PLoS One 9:e103556. CrossRef Medline

Rasband MN, Park EW, Vanderah TW, Lai J, Porreca F, Trimmer JS (2001) Distinct potassium channels on pain-sensing neurons. Proc Natl Acad Sci U S A 98:13373-13378. CrossRef Medline

Renganathan M, Cummins TR, Waxman SG (2001) Contribution of $\mathrm{Na}(\mathrm{v}) 1.8$ sodium channels to action potential electrogenesis in DRG neurons. J Neurophysiol 86:629-640. Medline

Rettig J, Wunder F, Stocker M, Lichtinghagen R, Mastiaux F, Beckh S, Kues W, Pedarzani P, Schröter KH, Ruppersberg JP (1992) Characterization of a shaw-related potassium channel family in rat brain. EMBO J 11:24732486. Medline

Ritter AM, Mendell LM (1992) Somal membrane properties of physiologically identified sensory neurons in the rat: effects of nerve growth factor. J Neurophysiol 68:2033-2041. Medline

Ritter DM, Ho C, O'Leary ME, Covarrubias M (2012) Modulation of Kv3.4 channel $\mathrm{N}$-type inactivation by protein kinase $\mathrm{C}$ shapes the action potential in dorsal root ganglion neurons. J Physiol 590:145-161. CrossRef Medline

Ritter DM, Zemel BM, Lepore AC, Covarrubias M (2015a) Kv3.4 channel function and dysfunction in nociceptors. Channels 9:209-217. CrossRef Medline

Ritter DM, Zemel BM, Hala TJ, O’Leary ME, Lepore AC, Covarrubias M (2015b) Dysregulation of Kv3.4 channels in dorsal root ganglia following spinal cord injury. J Neurosci 35:1260-1273. CrossRef Medline

Rola R, Witkowski G, Szulczyk PJ (2003) Voltage-dependent K+ currents in rat cardiac dorsal root ganglion neurons. Neuroscience 119:181-191. CrossRef Medline

Rudy B, McBain CJ (2001) Kv3 channels: Voltage-gated K+ channels designed for high-frequency repetitive firing. Trends Neurosci 24:517-526. CrossRef Medline

Rudy B, Chow A, Lau D, Amarillo Y, Ozaita A, Saganich M, Moreno H, Nadal MS, Hernandez-Pineda R, Hernandez-Cruz A, Erisir A, Leonard C, VegaSaenz de Miera E (1999) Contributions of Kv3 channels to neuronal excitability. Ann N Y Acad Sci 868:304-343. CrossRef Medline

Rush AM, Cummins TR, Waxman SG (2007) Multiple sodium channels and their roles in electrogenesis within dorsal root ganglion neurons. J Physiol 579:1-14. CrossRef Medline

Safronov BV, Bischoff U, Vogel W (1996) Single voltage-gated K+ channels and their functions in small dorsal root ganglion neurones of rat. J Physiol 493:393-408. CrossRef Medline

Scholz A, Gruss M, Vogel W (1998) Properties and functions of calciumactivated $\mathrm{K}+$ channels in small neurones of rat dorsal root ganglion studied in a thin slice preparation. J Physiol 513:55-69. CrossRef Medline

Scroggs RS, Fox AP (1992) Multiple Ca2 + currents elicited by action potential waveforms in acutely isolated adult rat dorsal root ganglion neurons. J Neurosci 12:1789-1801. Medline

Sculptoreanu A, Artim DE, de Groat WC (2009) Neurokinins inhibit low threshold inactivating $\mathrm{K}+$ currents in capsaicin responsive DRG neurons. Exp Neurol 219:562-573. CrossRef Medline

Shao LR, Halvorsrud R, Borg-Graham L, Storm JF (1999) The role of BKtype $\mathrm{Ca} 2+$-dependent $\mathrm{K}+$ channels in spike broadening during repetitive firing in rat hippocampal pyramidal cells. J Physiol 521:135-146. CrossRef Medline

Shevchenko T, Teruyama R, Armstrong WE (2004) High-threshold, Kv3like potassium currents in magnocellular neurosecretory neurons and their role in spike repolarization. J Neurophysiol 92:3043-3055. CrossRef Medline

Shu Y, Yu Y, Yang J, McCormick DA (2007) Selective control of cortical 
axonal spikes by a slowly inactivating $\mathrm{K}+$ current. Proc Natl Acad Sci U S A 104:11453-11458. CrossRef Medline

Sonner PM, Filosa JA, Stern JE (2008) Diminished A-type potassium current and altered firing properties in presympathetic PVN neurones in renovascular hypertensive rats. J Physiol 586:1605-1622. CrossRef Medline

Storm JF (1988) Temporal integration by a slowly inactivating K+ current in hippocampal neurons. Nature 336:379-381. CrossRef Medline

Sundt D, Gamper N, Jaffe DB (2015) Spike propagation through the dorsal root ganglia in an unmyelinated sensory neuron: a modeling study. J Neurophysiol 114:3140-3153. CrossRef Medline

Tigerholm J, Petersson ME, Obreja O, Lampert A, Carr R, Schmelz M, Fransén E (2014) Modeling activity-dependent changes of axonal spike conduction in primary afferent C-nociceptors. J Neurophysiol 111:17211735. CrossRef Medline

Vaughn AH, Gold MS (2010) Ionic mechanisms underlying inflammatory mediator-induced sensitization of dural afferents. J Neurosci 30:78787888. CrossRef Medline

Wallner M, Meera P, Toro L (1999) Molecular basis of fast inactivation in voltage and $\mathrm{Ca} 2+$-activated $\mathrm{K}+$ channels: a transmembrane beta-subunit homolog. Proc Natl Acad Sci U S A 96:4137-4142. CrossRef Medline

Wu RL, Barish ME (1992) Two pharmacologically and kinetically distinct transient potassium currents in cultured embryonic mouse hippocampal neurons. J Neurosci 12:2235-2246. Medline

Xia XM, Ding JP, Lingle CJ (1999) Molecular basis for the inactivation of $\mathrm{Ca} 2+-$ and voltage-dependent BK channels in adrenal chromaffin cells and rat insulinoma tumor cells. J Neurosci 19:5255-5264. Medline
Xia XM, Ding JP, Zeng XH, Duan KL, Lingle CJ (2000) Rectification and rapid activation at low $\mathrm{Ca} 2+$ of $\mathrm{Ca} 2+$-activated, voltage-dependent $\mathrm{BK}$ currents: consequences of rapid inactivation by a novel beta subunit. J Neurosci 20:4890-4903. Medline

Yang EK, Takimoto K, Hayashi Y, de Groat WC, Yoshimura N (2004) Altered expression of potassium channel subunit mRNA and alpha-dendrotoxin sensitivity of potassium currents in rat dorsal root ganglion neurons after axotomy. Neuroscience 123:867-874. CrossRef Medline

Yeung SY, Thompson D, Wang Z, Fedida D, Robertson B (2005) Modulation of Kv3 subfamily potassium currents by the sea anemone toxin BDS: significance for CNS and biophysical studies. J Neurosci 25:8735-8745. CrossRef Medline

Zamponi GW, Lewis RJ, Todorovic SM, Arneric SP, Snutch TP (2009) Role of voltage-gated calcium channels in ascending pain pathways. Brain Res Rev 60:84-89. CrossRef Medline

Zhang XF, Gopalakrishnan M, Shieh CC (2003) Modulation of action potential firing by iberiotoxin and NS1619 in rat dorsal root ganglion neurons. Neuroscience 122:1003-1011. CrossRef Medline

Zhang XL, Mok LP, Katz EJ, Gold MS (2010) BKCa currents are enriched in a subpopulation of adult rat cutaneous nociceptive dorsal root ganglion neurons. Eur J Neurosci 31:450-462. CrossRef Medline

Zhang XL, Mok LP, Lee KY, Charbonnet M, Gold MS (2012) Inflammation-induced changes in $\mathrm{BK}(\mathrm{ca})$ currents in cutaneous dorsal root ganglion neurons from the adult rat. Mol Pain 8:37-8069-8-37. CrossRef Medline 